Agro-Science Journal of Tropical Agriculture, Food, Environment and Extension Volume 12 Number 2 May 2013 pp. 35 - 39

ISSN 1119-7455

\title{
QUALITY EVALUATION OF YOGHURT BRANDS PRODUCED IN MAKURDI METROPOLIS
}

\author{
${ }^{* 1}$ Ikya, J. K., ${ }^{1}$ Eke M.O., ${ }^{1}$ Abela, V. A., \\ ${ }^{1}$ Department of Food Science and Technology, University of Agriculture, P.M.B. 2373, Makurdi, \\ Nigeria. \\ "1 Corresponding author: aveyina2012@gmail.com ,
}

\begin{abstract}
In this study, three yoghurt brands Tito yoghurt, Tito probiotic and Final yoghurt produced in Makurdi metropolis were randomly collected in different locations of Makurdi metropolis and subjected to sensory, chemical and microbiological quality analyses. Results on sensory quality attributes showed that Tito Yoghurt scored highest (8.20) on overall acceptability. The pattern followed similar trends on colour, mouth feel and flavour. Results on chemical properties showed that the per cent protein in the yoghurt samples were Tito yoghurt (27.2), Final yoghurt (23.7) and Tito probiotic (19.7). Results on microbiological evaluation on Total plate counts $(\mathrm{CFU} / \mathrm{ml})$ were Tito yoghurt $\left(2.10 \times 10^{2}\right)$, Tito probiotic $\left(2.04 \times 10^{2}\right)$ and Final yoghurt $\left(2.11 \times 10^{2}\right)$ and yeast and mould count (CFU/ml) were $3.02 \times 10^{2}, 3.04 \times 10^{2}$ and $1.09 \times 10^{2}$ respectively. Counts were within acceptable range and recommended for consumption. This study revealed that hygienic conditions were adopted in the production of yoghurt brands in Makurdi metropolis.
\end{abstract}

Keywords: Quality evaluation, Yoghurt brands, Quality attributes, Makurdi metropolis, hygienic conditions

\section{INTRODUCTION}

Yoghurt is a milk product and can serve as food for man. It also serves as a medium for microbial growth due to its high nutritional value. It plays an important role in human nutrition, health maintaining, therapeutic and dietetic functions ( Hughes and Hover, 1991). Yoghurt is perhaps one of the oldest fermented milk product known and consumed by large segments of our population either as a part of diet or as a refreshing beverages. It is a balanced food containing almost all the nutrients present in milk (Ayebo and Shahan, 1980; Deeth and Tamine, 1981). Yoghurt is a product of the lactic acid fermentation of milk. Fermentation of milk to yoghurt involves the action of microorganisms, principally the lactic acid bacteria. These microorganisms convert milk lactose into lactic acid and make milk sour (Kagan, 1985).

The consumption of yoghurt in Nigeria, precisely in Makurdi metropolis has increased during the last decade and it is taken as snack mainly by city dwellers. The only native milk product closely related to yoghurt is Nuno, a fermented or sour milk product consumed by people of Northern Nigeria. The nutritional benefit of yoghurt is due to milk constituents and exogenous living acid bacteria (Domagla, 2005). Lactobacillus bulgaris produces acetaldehyde that perfumes yoghurt and also produces lactic acid which helps to preserve the milk (Balows et al., 1991). Additional health benefits attributed to probiotic are the stimulation of the immune system, blood cholesterol reduction, vitamin synthesis, and anti-carcinogenesis and antibacteria activities. Yoghurt may aid digestion, ease diarrhea, boost immunity, protect against cancer ( Deeth and Tamine, 1981., Fernandez, 1988., Gibson et al.,1997). Yoghurt is more nutritious than milk in vitamin contents for its digestibility. It is also used as source of calcium and phosphorus (Foissy, 1983). Based on the rate of consumption, benefits and general acceptability of yoghurt in Makurdi metropolis there is need to evaluate the quality of yoghurt brands produced in Makurdi, to create wariness among common people about the existing situation of yoghurt brands and protect consumers health and right. This consideration forms the basis for the present research. 


\section{MATERIALS AND METHOD}

Three brands of yoghurt packaged in plastic bottles were purchase from Tito yoghurt plant and final yoghurt plant in Makurdi town. The samples were transported to the laboratory in a small cooler with some ice crystal in order to maintain the environment in which they were being purchased. They were coded, $(\mathrm{ABC})$ representing the three brands respectively. The samples were kept in a laboratory refrigerator form where samples were being drawn for analysis.

\section{Sensory Quality Evaluation}

A 15 member panelist or judges comprising of students of the college of Food Technology: (Food Science and Technology and Home Science and Management) of the University of Agriculture Makurdi, were used to assess the following quality attributes such as colour, mouth feel, flavor/aroma and general acceptability. A 9 point hedonic scale was used ( Iwe, 2002).

\section{Chemical Analysis of Yoghurt Crude Protein}

The micro-Kjeldahl method as describe by (AOAC, 2005) was used to determine the percentage crude protein of the three brands of yoghurt. The Kjeldahl method estimates the crude protein or total nitrogen matter (true protein as well as non-protein).

\section{Moisture Determination}

The moisture content of the three brands of yoghurt was determined using the force air oven dry method (AOAC, 2005). This method involves the measurement of the weight lost due to the evaporation of free water.

\section{Total Crude Fat Determination}

The total crude fat of yoghurt was determined by AOAC (2005). The sample was boiled in dilute hydrochloric acid to free the occluded and bound lipid fraction and is subsequently extracted within hexane or petroleum ether.

\section{Ash Determination}

The AOAC (2005) method of determining ash was used.

\section{pH Measurement}

The $\mathrm{pH}$ of the yoghurt samples was determined using a digital pH meter (model: WPACD 60) and Electronic Sensitive pH meter (model: PW 94 (31) Philips)

Total Titrable acidity (AOAC, 2005) An aliqust samle $(10 \mathrm{cml})$ was mixed with strring with $20 \mathrm{ml}$ distilled water using a glass ord phrio phthoation indiceter $(1 \mathrm{ml})$ was added and titrated with $0.1 \mathrm{M}$ of
$\mathrm{NaOH}$ to a pink colour. The procedure was repeated for the other samples. Total titrable acidity calculated as percentage lactic acid was determined as shown below;

$$
\% \text { Lactic acid }=1 \mathrm{ml} \mathrm{NaOHx} 0.09
$$

$\mathrm{X} \mathrm{ml}$

$\% \mathrm{TTA}=$ volume at base $\mathrm{X}$ normally of base

$$
\% \mathrm{TT}=\text { volume at base } \mathrm{X} \text { normally of base }
$$

$\mathrm{X}$ ml equivalent $\mathrm{X} 100$

$$
=\frac{\text { weightofpredominantacid }}{\text { Sample }} \times 100
$$

Microbial Analysis

\section{Total Yeast and Mould Count}

The method described by Adegoke (2004) for Total yeast and Mould counts in dairy milk was used.

\section{Total Bacteria Count}

Bradshaw (1979) method of the plate count of bacteria in milk was adopted for the total bacteria count in the yoghurt.

\section{Coli form Test}

The liquid media method as described by Collins et al (1989) for dairy milk was adopted.

\section{RESULTS \\ Sensory Quality Evaluation}

The sensory quality evaluation was calculated using ANOVA and Turkeys test to check the level of significance between the three brands of yoghurt, which are Tito yoghurt, Tito probiotic, and final yoghurt respectively. The results of the sensory attributes from (Table 1) indicate that Tito yoghurt rates higher in all the sensory attributes from colour, mouth feel or taste, flavor and aroma to general acceptability. This is followed closely by Tito probiotic and finally by final yoghurt which was rated lower in all the attributes compared.

There was no significant difference $(\mathrm{P} \leq 0.05)$ between final and Tito probiotic with respect to their colour and mouth feel and taste conversely the two brands were significantly different $\mathrm{P} \leq 0.05$ ) from Tito yoghurt both in colour and mouth feel. There was however, no significant difference at $(P \geq 0.05)$ with respect to mouth feel or taste between Tito and Tito probiotic. It was also noted that there was no significant difference at $(\mathrm{P} \geq 0.05)$ between Tito, Tito probiotic and final yoghurt with regards to flavour and aroma

\section{Chemical Properties}

The physical and chemical properties of Tito yoghurt, Tito probiotic and Final yoghurt are shown in Table 2. The results indicated that Tito yoghurt contained 82.86 $\%$ moisture, Tito probiotic $81.76 \%$ while Final yoghurt on the other hand contained the highest 
amount of moisture of $83.64 \%$. Tito yoghurt contained high ash content of $1.20 \%$ when compared to Tito probiotic $0.88 \%$ and Final yoghurt $0.88 \%$ respectively. Tito yoghurt was found to have the highest content of crude protein when compared to Tito probiotic and Final yoghurt. Similarly, Tito had the highest amount of fat content of $1.90 \%$ as compared to Final yoghurt $1.48 \%$ and Tito probiotic $1.30 \%$ with the lowest fat content.

The pH of Final Tito yoghurt was 3.70, which was lower as compared to Tito yoghurt 3.80 and Tito probiotic 3.90 respectively. The total titrable acidity (percent lactic acid) of Tito yoghurt was 0.93 which was higher compared to Final 0.92 and Toto probiotic 0.84 , respectively.

Table 1: Sensory Quality attributes of Three Brands of Yoghurt Produced in Makurdi Metropolis.

\begin{tabular}{lllll}
\hline Sensory attributes & Tito Yoghurt & Tito Probiotic & Final Yoghurt & LSD \\
\hline Colour & $8.40^{\mathrm{a}}$ & $7.80^{\mathrm{b}}$ & $7.60^{\mathrm{b}}$ & 0.48 \\
Mouth feel & $7.50^{\mathrm{a}}$ & $7.20^{\mathrm{a}}$ & $6.60^{\mathrm{c}}$ & 0.40 \\
Flavour & $7.50^{\mathrm{a}}$ & $7.00^{\mathrm{b}}$ & $7.40^{\mathrm{a}}$ & 0.30 \\
General Acceptability & $8.20^{\mathrm{a}}$ & $7.00^{\mathrm{b}}$ & $7.20^{\mathrm{b}}$ & 0.80 \\
& & & & \\
\hline
\end{tabular}

The values with different superscript across rows are significantly different at $(\mathrm{P}<0.05)$.

The values are means of 15 judges and a 9 point Hedonic scale, (Scoring) of three brands of yoghurt where $9=$ like extremely $8=$ like very much, $7=$ like moderately, $6=$ like slightly, $5=$ neighed like nor dislike, $4=$ dislike slightly, $3=$ dislike moderately, $2=$ dislike very much and $1=$ dislike extremely.

Table 2: Chemical Properties of Three Brands of Yoghurt Produce in Makurdi Metropolis

\begin{tabular}{llllr}
\hline & Tito Yoghurt & Tito Probiotic & \multicolumn{2}{c}{ Final Yoghurt } \\
PARAMETERS & LSD & & & \\
\hline Moisture & $82.86^{\mathrm{a}} \pm 0.08$ & $81.76^{\mathrm{b}} \pm 0.13$ & $83.64^{\mathrm{a}} \pm 0.06$ & 0.92 \\
content $(\%)$ & $2.72^{\mathrm{a}} \pm 0.14$ & $1.97^{\mathrm{b}} \pm 0.11$ & $2.37^{\mathrm{a}} \pm 0.08$ & 0.38 \\
Protein $(\%)$ & & & & \\
Fat $(\%)$ & $1.90^{\mathrm{a}} \pm 0.11$ & $1.30^{\mathrm{c}} \pm 0.06$ & $1.48^{\mathrm{c}} \pm 0.06$ & 0.35 \\
Ash $(\%)$ & $1.20^{\mathrm{a}} \pm 0.10$ & $0.88^{\mathrm{b}} \pm 0.06$ & $0.88^{\mathrm{b}} \pm 0.08$ & 0.20 \\
TTA $(\%)$ & $0.93^{\mathrm{a}} \pm 0.10$ & $0.84^{\mathrm{b}} \pm 0.08$ & $0.92^{\mathrm{a}} \pm 0.06$ & 0.05 \\
pH & $3.80^{\mathrm{b}} \pm 0.06$ & $3.90^{\mathrm{z}} \pm 0.10$ & $3.70^{\mathrm{a}} \pm 0.11$ & 0.12 \\
\hline
\end{tabular}

Values are means \pm standard deviation of triplicate determination values with different superscripts across rows are significantly different.

Table 3: Microbial Quality of Three Brands of Yoghurt Produced in Makurdi Metropolis

\begin{tabular}{llll}
\hline Parameter & Tito Yoghurt & Tito Probiotic & Final Yoghurt \\
\hline Total bacterial count $(\mathrm{Cfu} / \mathrm{m})$ & $2.10 \times 10^{2}$ & $2.04 \times 10^{2}$ & $2.11 \times 10^{2}$ \\
Yeast and mould count $(\mathrm{cfu} / \mathrm{m})$ & $3.02 \times 10^{2}$ & $3.04 \times 10^{2}$ & $1.09 \times 10^{2}$ \\
Coliform count $(\mathrm{cfu} / \mathrm{ml})$ & $\mathrm{Nil}$ & $\mathrm{Nil}$ & $\mathrm{Nil}$ \\
\hline
\end{tabular}

Values are means of duplicate determinations

\section{The microbial}

The result showed that Final yoghurt contained the highest levels of total bacterial count compared to Tito yoghurt and Tito probiotic with values of $2.11 \times 10^{2}$ $\mathrm{Cfu} / \mathrm{ml}, 2.10 \times 10^{2} \mathrm{cfu} / \mathrm{ml}$ and $2.04 \times 10^{2} \mathrm{Cfu} / \mathrm{ml}$ respectively. Similarly, the total yeast and mould count in Tito probiotic was higher than those in Tito yoghurt and Final yoghurt with the value of $3.04 \times 10^{2} \mathrm{Cfu} / \mathrm{ml}$ and $1.09 \times 10^{2} \mathrm{Cfu} / \mathrm{ml}$. The coli form test results was negative for all the brands

\section{DISCUSSION}

Sensory quality Evaluation: The sensory analysis result of the panel studies carried on the three brands of yoghurt; Tito yoghurt, Tito probiotic and Final yoghurt and incubated $37 \pm 22^{\circ} \mathrm{C}$ is as shown in Table 1.The result indicated that Tito yoghurt was more preferred and highly scored above Tito probiotic and Final yoghurt and respectively by sensory panelist in respect to all the sensory attributes, which includes colour, mouth feel, flavour and general acceptability. Tito probiotic ranked next to Tito yoghurt and lastly by Final yoghurt. There was no significant difference at 
$(\mathrm{P} \geq 0.05)$ between final and Tito probiotic in terms of their colour and mouth feel/taste whereas the two brands were significantly different at $(\mathrm{P} \leq 0.05)$ from Tito yoghurt both in colour and mouth feel/taste. It was also noted that, no significant difference at $(\mathrm{P} \leq 0.05)$ between Tito, Tito probiotic and Final yoghurt was evident with regards to flavor/aroma. These similarities could be due to the fact that the three brands of yoghurt were both produced using the same flavourings which could be either banana or vanilla flavor.

For Tito probiotic and final yoghurt, no significant difference at $(\mathrm{P} \geq 0.05)$ was observed by the panelist with regards to the general acceptability while there was a difference $(\mathrm{P} \leq 0.05)$ between Tito yoghurt and the other two brands. Yoghurt, is generally known by people to be white and as such any other color in contrast to that might be unacceptable. The high sensory quality of Tito yoghurt as compared to the other brands might be due to careful and hygienic handling and processing methods especially the heating and pasteurization as well as the storage conditions. The heating/pasteurization enzyme and anti-nutritional factors contained in the milk can also improve colour.

\section{Chemical Properties}

Chemical properties of Tito yoghurt, Tito probiotic and final yoghurt was obtained as shown in Table 2 . The final proximate composition is closely related. Tito yoghurt has the highest proximate results which was followed by final yoghurt and then Tito probiotic. Cow milk and human milk contains about $3.8 \%$ and $1.1 \%$ respectively FAO (1968). Final yoghurt has a moisture content of $83.64 \%$ which is significant higher $\mathrm{P} \leq 0.05$ than Tito $82.86 \%$ and Tito probiotic $81.76 \%$. The protein content of Tito was $2.72 \%$, Tito probiotic $1.97 \%$ and Final $2.31 \%$. The fat content of the tree samples were; $1.90 \%$ for Tito, $1.30 \%$ for Tito probiotic and $1.48 \%$ for Final. There was an inverse relationship between moisture, protein and fat content. The higher the moisture content, the higher the fat and the lower the protein content. The ash content of Tito yoghurt $(1.20)$ was significantly $(\mathrm{P}<0.05)$ higher than Tito probiotic (0.88) and final yoghurt (0.88.) This implies that Tito yoghurt contains more minerals in the composition than the other two brands and this could be due to the milk used as base raw material and at least due to processing procedures.

The percent lactic acids for the samples were; $0.93 \%$ in Tito yoghurt, $0.84 \%$ Tito probiotic and $0.92 \%$ for Final yoghurt respectively. This implies that Tito yoghurt with the highest percentage lactic acid will support the growth of lactic acid bacteria than the other two brands. The acidity was in accordance with that reported by Ihekoronye and Ngoddy (1985) to be 0.85 $0.95 \%$ and $\mathrm{pH}$ of $4-4-5$. The $\mathrm{pH}$ of the samples from the analysis was 3.80 for Tito yoghurt, 3.90 for Tito probiotic and 3.70 for Final yoghurt. This falls within range reported by Ihekoronye and Ngoddy (1985).

\section{Microbial Quality}

Some microbiological requirements are set to control the count of microbial growth in food for safety purpose. These microbial requirements when tested by appropriate body such as International Commission of Microbiological Standards for Food (ICMSF) methods, the products should posses the following: shall be free from pathogenic organisms capable of development under normal condition of storage, shall not contain any substance originating from micro-organism in amounts which may be toxic and yeast and mould, shall not exceed $10 \mathrm{Cfu} / \mathrm{ml}$. Microbiological quality control plays a very important role in producing safe, nutritious, palatable and reasonable food product. The microbial counts result in Table 8 indicates that bacteria are most predominate micro-organisms in Tito yoghurt and Final yoghurt; whereas in Tito probiotic yeast and mould counts was greater and predominant. It could thus be said that the result of analysis in Table 8 falls within the safe limits of 10 colony forming unit $\mathrm{Cfu} / \mathrm{ml}$ specified for dairy products produced by the International Commission of Microbiological Standard for Foods (ICMSF), (1978.)

The result of total microbial load differ among three treatment reported by Muhammad et al, (2005) after inoculating with L. bulgaricus and S. thermophilus at $45 \%$ shows the highest value of $.073 \times 108 \mathrm{Cfu} / \mathrm{ml}$ for powdered milk yoghurt and $0.75 \times 108 \mathrm{Cfu} / \mathrm{ml}$ soy-milk yoghurt. The difference between the results reported by Muhammad et al.(2005) was not significantly different from results shown in table 8 of this project work. Microbial growth is an autocatalytic process and inoculation with starter culture might have been responsible for the high total microbial load at even low inoculation concentration. It is also reported that the whole cow milk yoghurt, powdered milk yoghurt and soy-milk inoculated with low culture concentration at low inoculation temperature of $25^{\circ} \mathrm{c}$ has low total microbial load which could be attributed to slow rate of growth of the mesophiles at temperature less than $30^{\circ}$ c. Muhammad et al., (2005).

Karleskind et al.(1991) reported a mean viable yoghurt culture cells of $1.49 \times 10^{9} \mathrm{Cfu} / \mathrm{ml}$ in milk based yoghurt against $2.57 \times 10^{8} \mathrm{Cfu} / \mathrm{ml}$ in soy -milk based yoghurt inoculated with $0.1 \%(\mathrm{v} / \mathrm{v})$ lactic acid incubated at $40^{\circ} \mathrm{c}$ The value is slightly higher than that shown in Table 8 and this difference could be attributed to difference in inoculation temperature, the particular medium or pure culture and strain of bacteria used.

The results of total yeast and mould count in three samples of yoghurt were significantly high especially in Tito probiotic $(3.04 \times 102 \mathrm{Cfu} / \mathrm{ml})$ as against Tito 
Ikya, J. K., Eke M.O., Abela, V. A.,

$(3.02 \times 102 \mathrm{Cfu} / \mathrm{ml})$ and final yoghurt $(1.09 \times 102$ $\mathrm{Cfu} / \mathrm{ml})$. This count could be due to poor hygienic processes during processing, handling and storage and also the nature or safety state of the raw materials used; although the result was in the acceptable range reported by Muhammad et al. (2005) for dairy milk and milk products. They reported that the total yeast and mould counts in milk should be within the range of hundreds for acceptability and consumption.

The result of coli-form test in the yoghurt samples was negative. The total absence or non-existence of coliform might be due to the fact that the water used for production was totally free of Coli-form bacteria which mean that the claim of yoghurt producing companies using treated water for production is correct. In conclusion, Tito yoghurt was highly preferred by the panelist as compared to Tito probiotic and Final yoghurt in respect to all the sensory attributes. The level of preference was followed by Tito probiotic and finally Final yoghurt. The results of the research show that Tito yoghurt has the highest proximate composition (Protein, Fat and Ash) and it's followed closely by Final yoghurt and then by Tito probiotic respectively. The result of the microbial analysis were within the safe limits of 10 colony forming units' $\mathrm{Cfu} / \mathrm{ml}$ per gram specified for dairy products as recommended by the International Commission of Microbiological Standard for Foods.

\section{ACKNOWLEDGMENTS}

The authors wish to acknowledge the Department of Food Science and Technology, University of Agriculture Makurdi, Nigeria for providing the enabling environment for the research

\section{REFERENCES}

Adegoke, G.O (2004). Understanding Food Microbiology $2^{\text {nd }} \quad$ Edition Alleluia ventures Ltd. Pp 127-207.

Ayebo A.D and Shahan K.M (1980). Role of cultured dairy products in the diet cult. Dairy product. J.15(4): 21.

AOAC ( 2005). Official Methods of Analysis Association of Official Analytical Chemist. $18^{\text {th }}$ Edition Washington D.C.

Balows, H.G, Truper M. Dworkin W, Harder KHS (1991). The Prokaryote. A Handbook on the Biology of Bacteria. 70:1547.

Bradshaw, J.L (1979). Laboratory Microbiology, $3^{\text {rd }}$ Edition. W.B Saunder Company, Philadelphia London Toronto. Pp 138139.
Collins, C H Patricis, M L. and Grange J.M. (1989). "Microbiological Methods" $6^{\text {th }}$ edition Butterwort pp 129-215.

Deeth, H.C, AY Tamine (1981). Yoghurt Nutritive and Therapeutic Aspects. J. Food Protect: 55:44-78.

Domagla, J. (2005). Texture of Yoghurt and BioYoghurts from Goats milk depending on starter Culter type. Milch Wissencchaft, 60(3): 289-292.

Fernades, C.F, K.M Shahani, M.A. Amer (1988). Control of Diarrhea by lactobacillus. $J$. Appl. Nutr. 40(1):32.43.

Foissy, H. (1983). Nutritional and Physiological aspects of yoghurt. J. food Sci. Technology Abstr. 16(3): 2404-24089.

Gibson, G.R, J.M. Savedra, Macferlane G., Macferlane (1997). Probiotics and Intestinal Infection, "a review" Chapman and Hall, London, Pp. 55-61.

Hughes D.B, Hover D.G (1991). Bifidio bacteria their potential for use in Amercan diary products, Food Technol 45, 74-83

Ikekoronye, A.I., and Ngoddy, P.O. (1985). Integrated Food Science and Technology for the Tropics. Macmillan, Education Ltd. London and Oxford. 345 and 357.

Iwe. M.O. (2002). Handbook of sensory method, and Analysis Rejoint Communication Services Ltd Enugu

Kagan, J. (1985). Yoghurt a rising star in the dairy industry. Cult. Dairy prod. J. 20(1): 2429.

Karleskind, D., Laye, I., Hollin, E. and Moor, C.V. (1991). Improving acid Production in soy-based yoghurt by adding cheese whey protein and mineral salts. Journal of Food Science. 55:999-1001.

Kleyn, D.H, J.M.O Neil, L.B. Hare (1979). Consistence and Compositional Characteristics of commercial yoghurt. $J$. dairy Sci. 62(4): 1032-1034.

Muhammad, B.F., Abubakar, M.M., Adegbola, T.A. and Oyawoye, E.O. (2005). Effects of culture concentration and noculaton Temperatuer on physico-Chemical, Microbial and organoleptic Properties of yoghurt. Nigerian food journal. 156-165. Nigeria industrial standard (NIS 337:2004). 